\title{
Homage to Prof. Dr. Danielle Balériaux, elected as honorary member of ESNR 2009
}

\author{
P. M. Parizel • G. Rodesch
}

Published online: 2 December 2009

(C) Springer-Verlag 2009

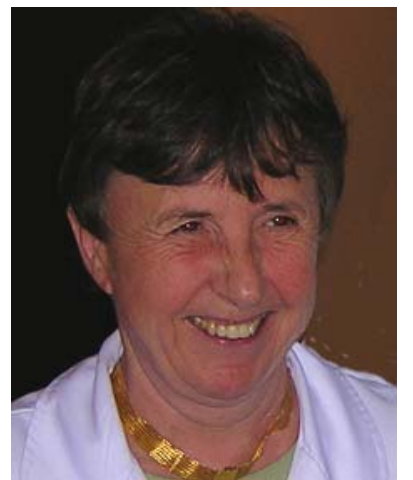

Danielle Balériaux was born in Ostend, Belgium. She studied medicine at the Université Libre de Bruxelles (ULB, Free University of Brussels) and graduated in 1969 magna cum laude (avec grande distinction) as "Docteur en Médecine, Chirurgie et Obstétrique" (M.D.). Given her keen interest in neuroscience and imaging, she decided to apply for residency training in radiology with Prof. Dr. Louis Jeanmart at the famous Jules Bordet Institute in Brussels, where the neurosurgical department of the ULB was located. She rapidly sub-specialized in neuroradiology. Immediately after completing her training, she was appointed as staff radiologist in the same institute, where she was given the opportunity to develop "new" neuroradiological techniques such as pneumo(tomo)encephalography, cerebral angiography and computed tomography (CT). In the late 1970 s, she was invited to move to the newly opened Hôpital Erasme, the flagship academic teaching hospital of the ULB. She was successful in building a section

\footnotetext{
P. M. Parizel $(\bowtie)$

Department of Radiology,

Antwerp University Hospital and University of Antwerp,

Antwerp, Belgium

e-mail: paul.parizel@uza.be

\section{G. Rodesch}

Department of Diagnostic and Therapeutic Neuroradiology,

Hôpital Foch,

Paris, France

e-mail: g.rodesch@hopital-foch.org
}

of neuroradiology, which quickly earned a reputation for clinical and scientific excellence. In recognition of her academic and scientific achievements, she was appointed in 1981 as professor of neuroradiology at the ULB. Her hospital career flourished and the next year, in 1982, she became "chef de clinique" of neuroradiology; in 1992 she became "chef de service adjoint" in the department of radiology at Hôpital Erasme.

Throughout her distinguished career, Prof. Balériaux has always been at the cutting-edge of new technological developments in neuroradiology. In the 1970s she became one of the first physicians in Belgium to work with computed tomography. In the early 1980s, when magnetic resonance imaging (MRI) was still unknown to most radiologists, she was one the very first European neuroradiologists to fully understand the awesome potential of this new technique. She did not hesitate to travel regularly from Brussels to the Philips Medical Systems factory in The Netherlands to perform MRI scans on selected patients. Her pioneering work, in close collaboration with Philips engineers and scientists, helped to expand neuroradiological applications of MRI and quickly bring them to a very high level. She worked with enthusiasm and dedication to improve the quality of MRI examinations, and was at the forefront of many new ideas to study diseases of the central nervous system. In 1984, the first MRI unit in an academic institution in Belgium was installed in her department.

Prof. Balériaux has accumulated an impressive scientific curriculum vitae. She has authored or co-authored more than 170 peer-reviewed scientific papers and wrote more than 40 book chapters. She successfully introduced several important innovations in the organization of clinically oriented scientific research and teaching. She was editor of a series of educational CD-ROM's on neuroradiology. 
Throughout her career, her main topics of interest have always been magnetic resonance imaging, and the neuroradiology of spinal tumors. At Hôpital Erasme, she developed a close working association with Prof. Dr. J. Brotchi, professor and chairman of neurosurgery. The symbiotic relationship between neuroradiology and neurosurgery allowed their multi-disciplinary team to acquire an internationally recognized excellence in spinal cord tumors.

Prof. Balériaux has invariably been successful in her determination to integrate basic science with neuroradiological clinical applications. The dedication to her work, her willingness to collaborate with clinicians, and her unrelenting energy has made Prof. Balériaux an internationally recognized and respected neuroradiologist. She is especially well-known for her ground-breaking work on spinal cord tumors, a topic on which she became a world-leading authority. Moreover, she has always endeavored to combine her busy clinical practice with a strong interest in educational activities, both on a national and international level. Throughout the 1980's and 1990 's, she formed a "school" of young neuroradiologists, who came to her department as residents or fellows. Her former pupils and collaborators have spread far beyond the borders of Belgium to occupy positions of responsibility and respectability in the field of neuroradiology. In the early stage of her career, Danielle Balériaux participated in and later co-organized educational neuroradiology courses together with Prof. Dr. A. Wackenheim (Strasbourg) and Prof. Dr. L. Jeanmart (Brussels) in the framework of the Collège d'Enseignement Post-Universitarie de Radiologie (CEPUR). She was very active in European Society of Neuroradiology (ESNR), and from 1993 to 1996, she served as vice-president for this society. She was one of the co-founders of the European Course on Neuroradiology (ECNR) together with Prof. Dr. P. Lasjaunias (Paris), Prof. Dr. C. Manelfe (Toulouse) and Prof. Dr. U. Salvolini (Ancona). In 1986, in Brussels, she hosted the first course devoted to the spine and spinal cord, which ended the "first cycle" of ECNR. Since 1990, she was involved with the Erasmus Course on Magnetic Resonance Imaging (EMRI), and was responsible for the organization of the module "Central Nervous System II".
After the demise of prof. dr. M. Osteaux in 2004, she accepted the challenge of managing and co-ordinating the EMRI course program, and she assumed this responsibility until 2008. She was one of the first physicians in Europe to strengthen ties of scientific collaboration with China, and in 1994, she developed a partnership with Rui Jin Hospital affiliated to Shanghai Medical University $\mathrm{N}^{\circ} 2$ (now Jiatong University in Shanghai).

The achievements and successes of Prof. Dr. Danielle Balériaux did not go unnoticed. In 1985, she was awarded the "Assubel Prize" in Brussels. In Stockholm, she was a "Torgny Greitz lecturer" on neuroradiology. She became a member of the prestigious Royal Academy of Medicine of Belgium and a corresponding member of the Académie Nationale de Médecine Française (since 1999). She is honorary member of the Japanese Society of Neuroradiology and of the French Society of Radiology. She is a fellow of the International Society of Magnetic Resonance in Medicine (ISMRM). In 2006, in recognition of her international efforts and service to the country, she was appointed "Grand Officier de l'Ordre de Léopold" (Belgium's highest civilian honor).

Those of us, who had the privilege of working with her, will never forget the ambiance in the neuroradiology section at Hôpital Erasme, where Prof. Balériaux succeeded in creating a very special atmosphere, consisting of intense activity, friendship, critical discussion, and intellectual honesty. She always had a unique capability of attracting students and collaborators of great talent and commitment, to whom she succeeded in conveying her energy and enthusiasm. When the authors (P.M.P. and G.R.) were fellows in the neuroradiology section during the mid to late 1980s, Prof. Balériaux stimulated us to pursue a career in neuroradiology and gave us the means and scientific freedom to explore our scientific interests. We are therefore very happy and proud that Prof. Balériaux was elected as honorary member of the ESNR, we are honored that we were given the pleasant task to write this "homage", and we are deeply grateful for the scientific support, warmth, and friendship that she has bestowed upon us throughout her long and illustrious career. 